\title{
The Determinants of Born Global Companies Emergence in Central European Countries
}

\author{
Elena Pawęta
}

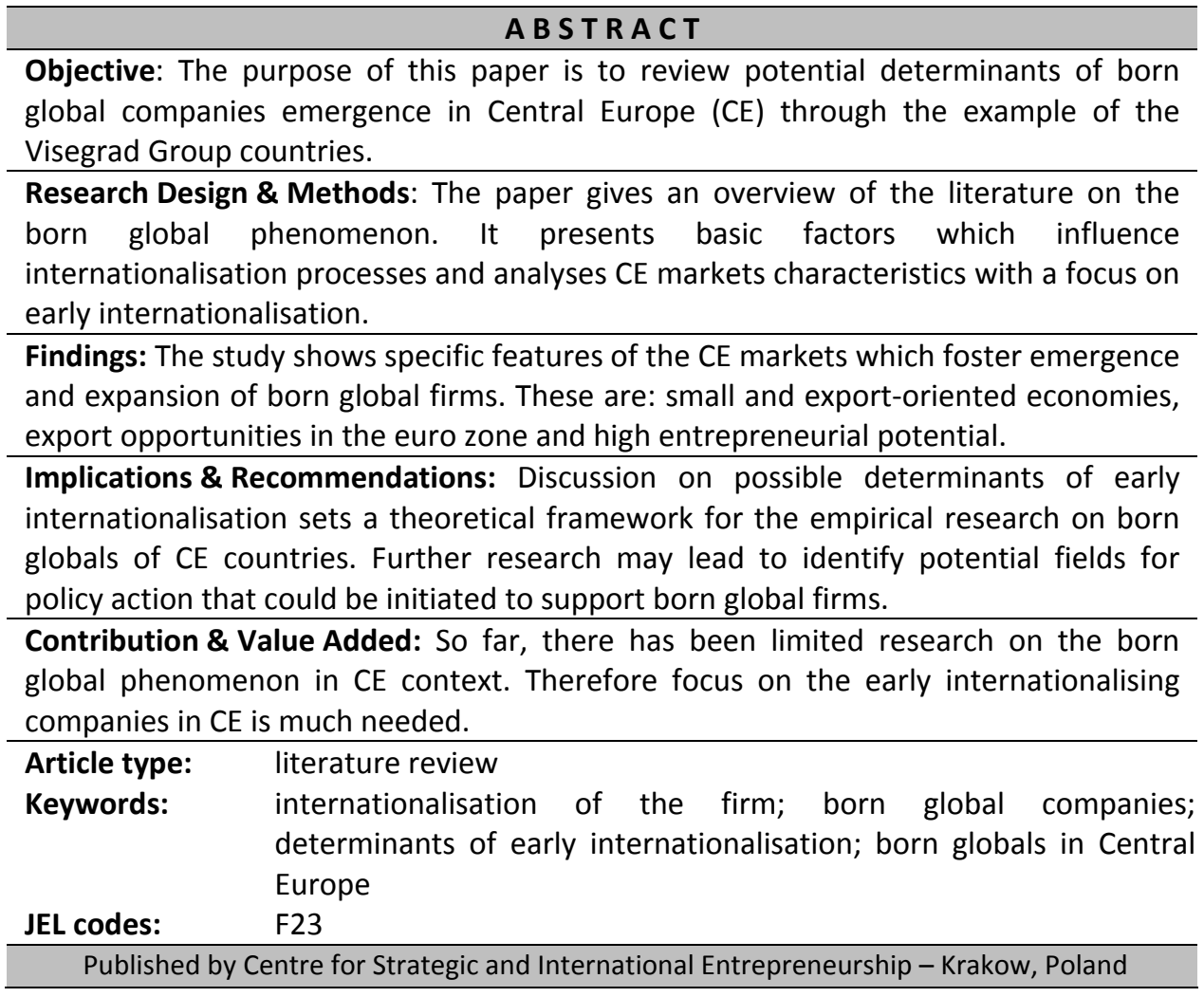

\section{Suggested citation:}

Pawęta, E., (2013). The Determinants of Born Global Companies Emergence in Central European Countries. Entrepreneurial Business and Economics Review, 1(2), pp. 41-50. 


\section{INTRODUCTION}

International business literature in the last decades has stated that not all companies follow the traditional internationalisation path. A part of these companies fall into the category of born globals - they start international operations immediately after their establishment. So-called born global firms first were mentioned in McKinsey \& Co. research (Rennie, 1993 quoted in Wach, 2012), which showed that companies do not need a strong domestic market in order to operate internationally.

The main goal of this paper is to analyse the potential for born global companies emergence by setting out potential determinants for early internationalisation in Central Europe (CE) through the example of the Visegrad Group countries. In order to achieve this goal, the following research question was asked: Does business environment in CE countries foster emergence of the born global companies?

Due to political conditions and transformation period, the CE economies have been incorporated into a global economic system only in 1991, and the European Union cooperation enabled them to fully participate in the global marketplace. In Poland the born global phenomenon became a subject for scientific research only in 2006 (Jarosiński, 2012).

This article discusses the key theoretical concepts related to rapid internationalisation of firms and possible motives for born global companies creation. Based on critical literature review, several factors fostering early internationalisation in CE countries, like: small domestic markets, export opportunities in the euro area and high entrepreneurial potential, are highlighted. The influence of the economic crisis on CE economies and businesses internationalisation is also discussed.

\section{LITERATURE REVIEW}

Traditional internationalisation theories such as the Uppsala model (Johannson \& Vahlne, 1977) suggest that firms first develop in their domestic market, establish a solid home base and go international in later stages of their life cycle. However, some companies do not follow this scheme but go global immediately after their founding. This phenomenon was first outlined in the 1993 research of the Australian manufacturers (Rennie, 1993) which showed that some companies are being born global. These findings have initiated further research on this topic.

The born global firm does not have a generally accepted definition in the international literature (Table 1). It is a relatively new concept, hence every researcher follows own definition, focusing on criteria such as share of foreign sales, time period before starting international activity or number of markets exported.

Gabrielsson et al. (2008) explain differences among the definitions. First Australian and US studies on born globals suggest that the foreign market share of such company should be at least 25\%, because Australia and the US are large countries with low export rate. However, European perspective demands a stricter definition, because any start-up from a small country with a specialized product could meet these requirements. That is why Finnish research (Luostarinen \& Gabrielsson, 2006) has suggested that at least $50 \%$ of sales should be to continents external to the one from which the firm originated.

Definitions of a born global firm may differ significantly, but they all focus on global mind-set of the founder. Although, empirical studies focus on tangible characteristics, 
global vision of an entrepreneur appears to be the key feature of early internationalising companies. The entrepreneur-related factors, pushing small and medium firms towards international activity shortly after inception, include international vision of the founders, their international experience, identification of a specific international opportunity, and desire to be an international market leader (Persinger et al., 2007). Born global companies are usually formed by proactive managers with an entrepreneurial mind-set who possess personal international network of contacts.

Table 1. Definitions of born global companies in the literature

\begin{tabular}{|l|c|c|c|c|}
\hline \multicolumn{1}{|c|}{ Author } & $\begin{array}{c}\text { Time before starting } \\
\text { international activity }\end{array}$ & $\begin{array}{c}\text { Share of } \\
\text { foreign sales }\end{array}$ & $\begin{array}{c}\text { Number of } \\
\text { markets }\end{array}$ & $\begin{array}{c}\text { Other } \\
\text { characteristics }\end{array}$ \\
\hline Rennie (1993) & 2 years & $75 \%$ & Multiple & $\begin{array}{c}\text { Global mind-set } \\
\text { from the outset }\end{array}$ \\
\hline $\begin{array}{l}\text { Knight \& Cavusgil } \\
(1996)\end{array}$ & 2 years & $25 \%$ & Global mind-set \\
from the outset \\
\hline $\begin{array}{l}\text { Madsen \& Servais } \\
\text { Chetty \& Campbell- }\end{array}$
\end{tabular}

Source: own elaboration based on (Gabrielsson \& Kirpalani, 2012).

Apart from entrepreneur characteristics, emergence of born global companies may be explained by a combination of external and internal factors. External factors facilitating early internationalisation are usually connected with sectoral, regional or national export culture, specific demand characteristics or foreign trade facilitators (Zahra \& George, 2002). Some regions with a strong export tradition in a certain sector create an "internationalisation culture" among entrepreneurs which leads to international activities enhancement (Eurofound, 2012). Born globals are more likely to emerge from small and open economies (Gabrielsson \& Kirpalani, 2012) because low domestic demand as well as active international demand foster international entrepreneurship. High risk levels and limited potential for starting up a domestic business are push factors for innovative start-ups to go international (Lejko \& Bojnec, 2011). The regulatory framework may also facilitate international activities (Eurofound, 2012). For example, favourable conditions on the home market supporting research and development incentives or beneficial framework conditions in foreign markets such as legal or tax incentives.

The internal determinants of early internationalisation are: suitable products or services, company mission to become internationally active, human or financial resources availability. A monopoly or near-monopoly position in a certain product or service provides a huge competitive advantage in the international business. It usually derives from tacit knowledge, unique product or process or other assets inseparable from the controlling firm (Cavusgil \& Knight, 2009). Many born globals internationalise because of a superior product that gains acceptance worldwide. Usually, it is an innovative, unique and high-quality product which allows to gain competitive advantage in the international markets. Global niche markets create a demand, which can be 
satisfied by highly technological, innovative companies with the strong international outlook.

\section{MATERIAL AND METHODS}

Critical literature review and data analysis are leading methods of this study. The potential determinants of born global companies emergence in CE was analysed through the example of the Visegrad Group countries - the Czech Republic, Hungary, Poland and Slovakia.

Journals and Internet platforms referring to the Visegrad countries served as sources of literature and data. For example, the official Internet portal of the Visegrad Group, which provides historical facts, official statements, essays and articles on the V4 group. Many articles were acquired online, from the Visegrad Revue webpage, or from the Visegrad Insight online newspaper.

Statistical data like GDP, export and unemployment levels derive from the Eurostat internet database platform.

\section{RESULTS AND DISCUSSION}

The question is whether the concept of born global companies is suitable for CE countries. Does business environment there foster emergence of such businesses? In order to discuss that, we analyse possible determinants of early internationalisation in CE countries through the example of the Visegrad Group countries.

There have been no previous extensive research on born global companies on the Central European scale. However, there is an evidence from the researchers from Poland (Berliński, 2006; Duliniec, 2011), the Czech Republic (Zapletalova, 2013), Slovenia (Lejko \& Bojnec, 2011), Hungary (Incze, 2010) that early internationalisation phenomenon exists. It seems clear that the next step is to combine these existing research findings in order to gain a broader understanding of born globals in CE countries.

\section{Small and Export-Oriented Central European Economies}

Andersson and Victor (2003) suggest that countries with small domestic markets present a higher propensity to generate born global companies than countries with large markets. CE countries, with their small and open economies, are highly export-oriented (Novák, 2010). Only Poland can rely more on its domestic demand and consumption because its market is relatively large. When we measure the share of exports in GDP (Figure 1), the Visegrad Group countries appear to be among comparatively largest exporters in the European Union. The highest percentages of exports in GDP are $95 \%$ for Hungary and $97 \%$ for Slovakia. The Czech Republic export ratio is $78 \%$. Therefore, we can confirm that small and export-oriented CE countries possess high potential to generate early internationalising companies. 


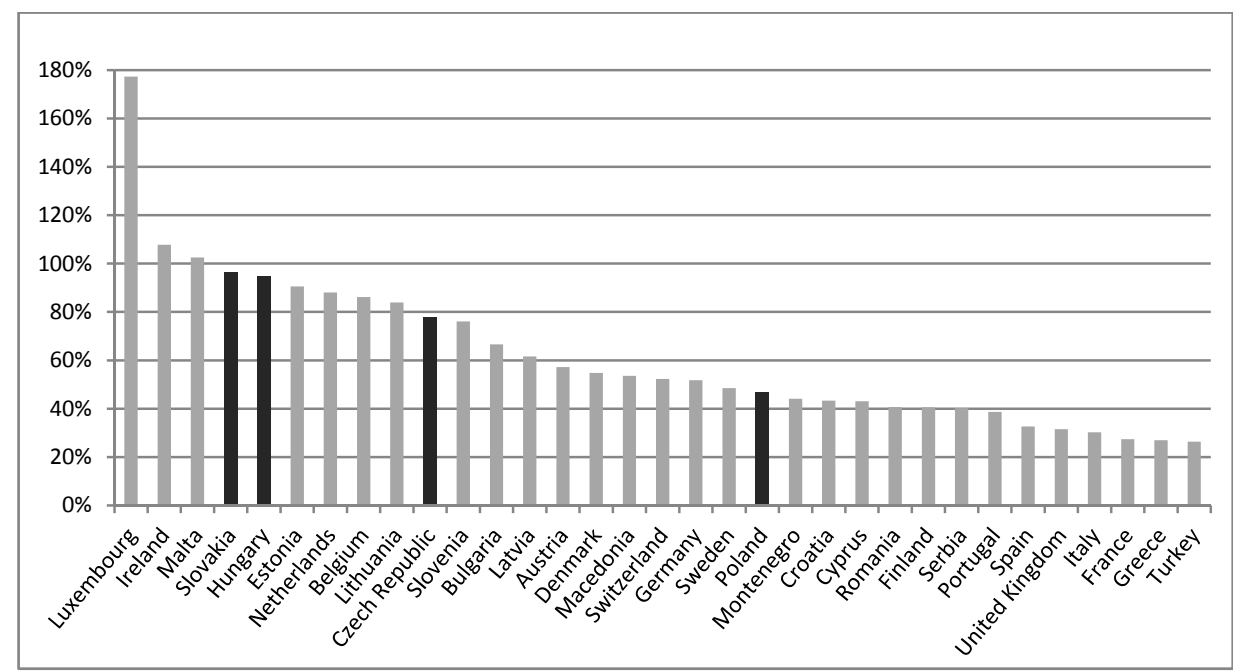

Figure 1. Export as a percentage of GDP in the Visegrad Group countries among the European Union countries in 2012

Source: own calculations based on (Eurostat, 2013).

\section{Export Opportunities in the European Union}

A significant external motive for early internationalisation is access to euro markets. Geographic proximity, lack of trade barriers and low psychological distance makes foreign European markets more attractive. German market, being the largest European economy, is the largest importer of the V4 countries' products and services (V4 Trade and Investment Observer, 2012). Visegrad countries export from $20 \%$ in case of Slovakia to more than $30 \%$ in case of the Czech Republic to Germany (Table 2). The interconnections of economies within the region are also visible - the Czech Republic is the second most important importer of Poland and Slovakia, which, in turn, are the second and third biggest importers of Czech goods (Špok, 2012).

Table 2. Top five importers of Visegrad Group goods and their share of total exports in 2011

\begin{tabular}{|c|c|c|}
\hline \multirow{6}{*}{ 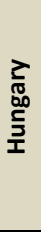 } & Partners & Share of total exports \\
\hline & Germany & $25.20 \%$ \\
\hline & Romania & $5.80 \%$ \\
\hline & Italy & $5.40 \%$ \\
\hline & Austria & $5.40 \%$ \\
\hline & Slovakia & $3.30 \%$ \\
\hline \multirow{6}{*}{$\begin{array}{l}\frac{0}{\frac{0}{0}} \\
\frac{\pi}{0} \\
0\end{array}$} & Partners & Share of total exports \\
\hline & Germany & $26.07 \%$ \\
\hline & Czech Republic & $6.20 \%$ \\
\hline & France & $6.13 \%$ \\
\hline & Italy & $5.36 \%$ \\
\hline & Russia & $4.52 \%$ \\
\hline
\end{tabular}

\begin{tabular}{|c|c|c|}
\hline \multirow{6}{*}{ 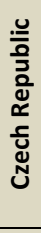 } & Partners & Share of total exports \\
\hline & Germany & $32.15 \%$ \\
\hline & Slovakia & $8.97 \%$ \\
\hline & Poland & $6.28 \%$ \\
\hline & France & $5.47 \%$ \\
\hline & Austria & $4.50 \%$ \\
\hline \multirow{6}{*}{ 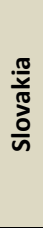 } & Partners & Share of total exports \\
\hline & Germany & $20.40 \%$ \\
\hline & Czech Republic & $14.20 \%$ \\
\hline & Poland & $7.30 \%$ \\
\hline & Austria & $7.00 \%$ \\
\hline & Italy & $5.30 \%$ \\
\hline
\end{tabular}

Source: adapted from (Špok , 2012). 
Depreciation of the local currencies, mainly in case of the Hungarian forint and the Polish zloty, have had a positive effect on sales to the foreign markets, as it has improved export profitability. Flexible exchange rates of national currencies allowed Czech, Hungarian and Polish economies to react swiftly to the business cycle downturn in the years 2008-2009, as their export prices became more competitive. In contrast, Slovakia, being a member of the common currency area, suffered in terms of competitiveness (Sobjak, 2013). Such favourable export conditions might enhance early internationalisation in CE countries.

\section{Entrepreneurial Potential in the Central European Countries}

Some studies focusing on decision to start a firm and become an entrepreneur suggest that rise the in unemployment leads to an increased start-up activity (Audretsch, 2001). The explanation of this phenomenon is the following: when people cannot find jobs matching their skills or income expectations, they more eagerly decide to start their own business. The global crisis caused the increase in unemployment in the CE countries, interrupting strong job creation dynamics that existed during the pre-crisis period (Sobjak, 2013). Figure 2 confirms the fact that in the years 2008-2011 in V4 countries the entrepreneurship level increased together with the rising unemployment.

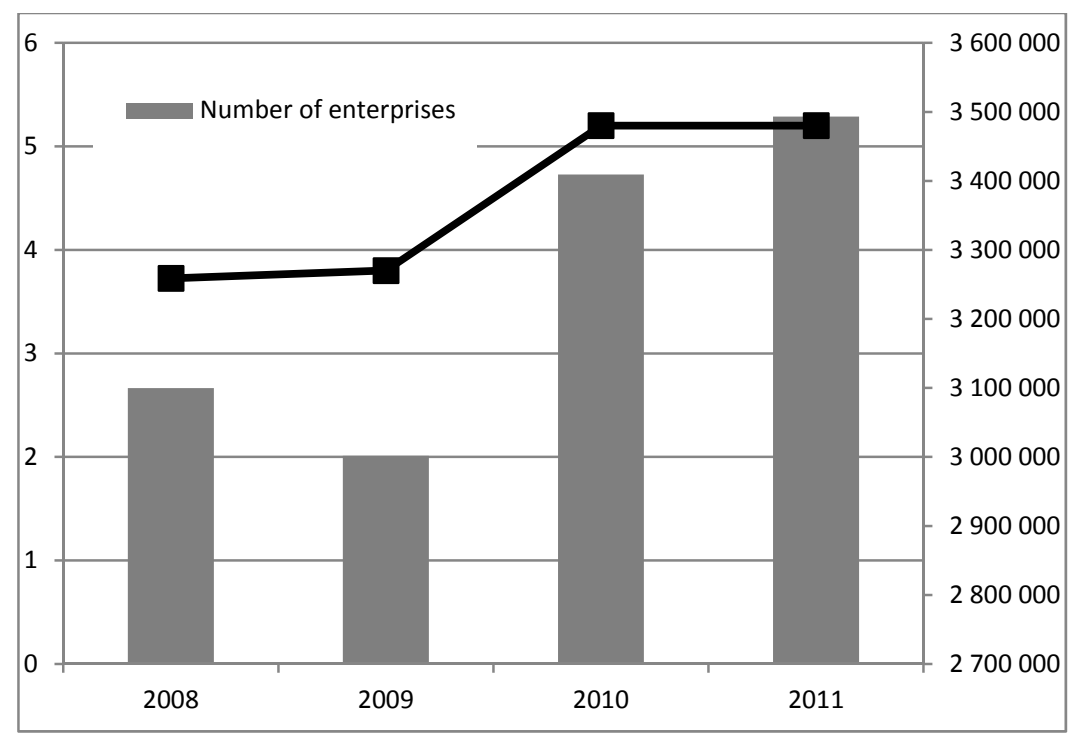

Figure 2. Average unemployment rate and total number of active enterprises in the Visegrad Group countries in the years 2008-2011

Source: own calculations based on (Eurostat, 2013).

According to the Global Entrepreneurship Monitor (GEM) 2012, research on entrepreneurial skills in European countries and the USA, Poland and Slovakia exhibited high entrepreneurial potential. The research was based on self-assessment of own capabilities and knowledge. Polish people assess their entrepreneurship potential rather high - 54\% declaring that they possess enough knowledge for starting and managing a company. That gives Poland a third position after the USA (56\%) and Macedonia (55\%). 
Slovakia also presents good results - $50 \%$ of the surveyed told that they possess the entrepreneurial capabilities (GEM Polska, 2012).

\section{Vulnerability of Born Global Companies}

According to the Eurofound report (2012), born globals contribute to current and future economic and labour market development in Europe. The estimated one-fifth of European start-ups can be considered to be born globals, and they are characterised by higher employment numbers than domestically oriented firms. They create high quality, well paid and stable work environments. Moreover, born global companies have a positive influence on the macroeconomic development through tax revenues or value chain effects caused by their innovativeness. Due to their pioneer character, they foster innovation and competitiveness on the market. After born global companies emerge, their vulnerability, due to their young age, lack of experience and established domestic markets, presents significant challenges for surviving on the market. Some authors note that these firms may need government support to realize their full potential (Eurofound, 2012).

Emergence of the born global companies in CE countries is enhanced by the specific economic and political situation of this region. Discussion on possible determinants of early internationalisation sets a theoretical framework for further empirical research on born globals functioning in CE countries and potential fields for government support.

\section{CONCLUSIONS}

Taking into consideration that CE economies are relatively small (with the exception of Poland), open and highly export-oriented, they probably possess the "internationalisation culture" which pushes start-ups abroad as they see opportunities in international business. High level of unemployment contributed to entrepreneurship growth in those countries, which, according to the latest GEM research, is on high level in CE countries. Therefore, we can assume that significant part of start-ups created in the export-oriented CE countries choose the international development path and become born global firms. Further research is needed to measure the percentage of born global companies among the CE exporters.

Political and economic changes in CE countries enabled some companies to adopt new internationalisation strategies. As those economies become more open, entrepreneurs see more opportunities on foreign markets and create born global companies, starting international activities from the inception.

Although born globals have been studied actively since the early 1990s, research on the born global phenomenon in CE context is limited. Further empirical research on born global activities in the Visegrad Group countries might address the following questions: how many born globals there are among the exporters, what are the determinants of their emergence, what are specific challenges they face. Answers to those questions may help to work out the potential fields for policy action that could be initiated to support born global firms. 


\section{REFERENCES}

Andersson, S. \& Victor, I., 2003, 'Innovative internationalization in new firms: born globals - the Swedish case', Journal of International Entrepreneurship, vol. 1, iss. 3, pp. 249-276.

Berliński, M., 2006, 'Firmy globalne od początku', Zeszyty Naukowe SGH, no. 20, Warsaw, pp. 132151.

Cavusgil, S.T. \& Knight, G., 2009, Born global firms: A new international enterprise, Business Expert Press, New York.

Chetty, S. \& Campbell-Hunt, C., 2004, 'A strategic approach to internationalization: A traditional versus a "born-global" approach', Journal of International Marketing, vol.12, no. 1, pp. 57-81.

Duliniec, E., 2011, 'Koncepcje przedsiębiorstw wcześnie umiędzynarodowionych. Rozważania terminologiczne', Gospodarka Narodowa, no. 1-2, pp. 63-80.

Eurofound, 2012, Born global: The potential of job creation in new international business, Publications Office of the European Union, 2012, Luxembourg, Available from: http://www.eurofound.europa.eu/publications/htmlfiles/ef1265.htm (accessed November 2013).

Eurostat, 2013,Available from: <http://epp.eurostat.ec.europa.eu/portal/page/portal/statistics /themes> (accessed December 2013).

Gabrielsson, M. \& Kirpalani, V.H.M., 2012, 'Overview, background and historical origin of born globals: Development of theoretical and empirical research. In M. Gabrielsson, \& V.H.M. Kirpalani (Eds), Handbook of research on born globals, Edward Elgar, Cheltenham.

Gabrielsson, M., Kirpalani, V.H.M., Dimitratos, P., Solberg, C.A., Zucchella, A., 2008, 'Born globals: Propositions to help advance the theory', International Business Review, vol. 17, no. 4, pp. 385-401.

GEM Polska, 2012, Poland 2012, Global Entrepreneurship Monitor report. Available from: <http://www.parp.gov.pl/index/more/36215> (accessed December 2013).

Incze, E., 2010, Hungarian Multinationals: A Time-Based Perspective of Firm Internationalization in a Transformational Country Context, Ph.D. thesis, Corvinus University of Budapest. Available from: <http://phd.lib.uni-corvinus.hu/607/2/Incze_Emma_end.pdf> (accessed December 2013).

Jarosiński, M., 2012, 'Urodzeni globaliści w badaniach na świecie i w Polsce', Studia i Prace Kolegium Zarzqdzania i Finansów, Zeszyt Naukowy no. 114, SGH, Warsaw, pp. 7-24.

Johanson, J. \& Vahlne, J.E., 1977, 'The internationalization process of the firm - A model of knowledge development and increasing foreign market commitments', Journal of International Business Studies, vol. 8, no. 1, pp. 23-33.

Lejko, I. \& Bojnec, S., 2011, 'The internationalisation of Slovenian SMEs: The born global concept in transition economies', in: Managing sustainability?, proceedings of the $12^{\text {th }}$ Management International Conference, Portorož, Slovenia, 23-26 November 2011, University of Primorska, Slovenia. Available from: <http://www.fm-kp.si/zalozba/ISBN/978-961-266-1120/papers/MIC4151.pdf> (accessed December 2013).

Luostarinen, R. \& Gabrielsson, M., 2006, 'Globalisation and marketing strategies for born globals in SMOPECs', Thunderbird International Business Review, vol. 48, no. 6, pp. 703-801.

Novák, T., 2010, 'Divergence in economic paths', The Slovak Spectator. Available from: $<$ http://www.visegradgroup.eu/other-articles/divergence-in-economic> (accessed December 2013).

Pencheva, S. 2013, 'How Effective is Visegrad's Export Promotion?', The Visegrad Revue online. Available from: <http://visegradrevue.eu/?p=1978> (accessed December 2013). 
Persinger, E.S., Civi, E. \& Vostina, S.W., 2007, 'The Born Global Entrepreneur In Emerging Economies', International Business and Economics Research Journal, vol. 6, no. 3, pp. 73-82.

Rennie, M.W., 1993, 'Global competitiveness: born global', McKinsey Quarterly, no. 4. Available from: <http://www.questia.com/library/journal/1G1-15424561/born-global> (accessed December 2013).

Sobjak, A., 2013, 'From the periphery to the Core? Central Europe and the economic crisis' The Polish Institute of International Affairs Policy Paper no. 7 (55), April 2013. Available from: <http://www.pism.pl/Publications/PISM-Policy-Paper-no-55> (accessed December 2013)..

Špok, R., 2012, 'Are Central European Economies Truly similar?' The Visegrad Revue online. Available from: < http://visegradrevue.eu/?p=776> (accessed December 2013).

The Visegrad Group webpage. Available from: <www.visegradgroup.eu> (accessed December 2013).

The Visegrad Revue online. Available from: <Visegradrevue.eu $>$ (accessed December 2013).

Thurik, A.R., Carree, M.A., van Stel, A. \& Audretsch, D.B., 2007, Does Entrepreneurship Reduce Unemployment? Tinbergen Institute Discussion Paper, no. 01-074/3 Available from: < http://www.econstor.eu/bitstream/10419/85927/1/01074.pdf >. (accessed December 2013).

V4 Trade and FDI Observer 2012, ICEG European Center, Budapest. Available from: <http://www.europeum.org/en/common-foreign-and-security-policy-and-defense/120publications/1854-v4-trade-and-investment-observer> (accessed December 2013).

Visegrad Insight. Available from: <http://visegradinsight.eu> (accessed December 2013).

Wach, K., 2012, Europeizacja małych i średnich przedsiębiorstw: rozwój przez umiędzynarodowienie. Wydawnictwo Naukowe PWN, Warszawa.

Zahra, S. \& George, G., 2002, 'International entrepreneurship: The current status of the field and future research agenda. In M.Hitt, D.Ireland, D.Sexton, M.Camp (Eds), Strategic entrepreneurship: Creating an integrated mindset, Blackwell, Oxford, pp. 255-288.

Zapletalová, Š., 2013, 'International Management: The Approaches to the International Process of Entrepreneurial Activities of the Czech Companies. In Global Virtual Conference, pp. 45-48. Available from: <http://www.gv-conference.com/archive/?vid=1\&aid=2\&kid=40101-63> (accessed December 2013). 


\section{Author}

\section{Elena Pawęta}

Currently a PhD student at the Centre for Finance and Accounting of SMEs at the University of Lodz, Poland. She is a graduate of the Saint-Petersburg State University, School of Management, Russia and the Technical University of Lodz, Faculty of Organization and Management. Her main research interests are entrepreneurship and business planning. She is particularly interested in the early internationalization of enterprises.

\section{Correspondence to:}

Mgr Elena Pawęta

University of Lodz

Faculty of Economics and Sociology

ul. POW 3/5, 90-255 Łódź, Poland

Elena.Paweta@gmail.com

Published by Centre for Strategic and International Entrepreneurship - Krakow, Poland 